\title{
The innovation gender gap in transition countries
}

\author{
Antonella Biscione ${ }^{1} \cdot$ Dorothée Boccanfuso $^{2} \cdot$ Raul Caruso $^{1}$ (D) \\ Annunziata de Felice ${ }^{3}$
}

Received: 12 October 2020 / Accepted: 13 July 2021 / Published online: 2 August 2021 (C) The Author(s) 2021

\begin{abstract}
This paper investigates the sources of the possible gender ownership gap in innovativeness in a set of Transition economies by means of firm-level data coming from the Business Environment and Enterprise Performance Survey (BEEPS V) conducted in 2012-2014. Through the Blinder-Oaxaca decomposition we highlight the factors explaining the differences in the propensity to innovate between femaleowned and male-owned firms. We find that the innovation disparity between firms with females among their owners and those having only male owners is mainly due to the differences in endowment effects. Tangible and intangible assets affect the innovation gap between the two groups of firms.
\end{abstract}

Keywords Blinder-Oaxaca decomposition · Non-linear model · Gender ownership · Innovation gap $\cdot$ Transition Countries

JEL Classification $\mathrm{O} 32 \cdot \mathrm{J} 12 \cdot \mathrm{P} 2$

\section{Introduction}

A sizable literature focused on innovation at the firm level does not consider directly the role of gender differences in fostering innovation. In particular, the role of female owners in the introduction of firm innovations are not well-understood. The lack of studies on gender perspective in innovative processes could be explained by the unrecognizable role played by people in the innovation filed.

Raul Caruso

raul.caruso@unicatt.it

1 Department of Economic Policy and CSEA, Università Cattolica del Sacro Cuore, CESPIC, Catholic University "Our Lady of Good Counsel", Tirana, Albania

2 Faculté de Gouvernance, Sciences Economiques et Sociales, Université Mohammed VI Polytechnique, Ben Guerir, Morocco

3 Department of Law, University of Bari Aldo Moro, Bari, Italy 
To the best of our knowledge, there are no empirical studies that explore the role of gender ownership for innovation output activities for the Transition Countries. Therefore, this paper is an attempt to bridge the gap by exploiting firm-level data drawn from the business environment and enterprise performance survey (BEEPS V) conducted in 2012-2014 jointly by the European Bank for Reconstruction and Development (EBRD) and the World Bank Group, a survey which includes information on several topics such as innovation, organization and management practices, employees, relations between enterprises and government, and other general information on firms.

In particular, our analysis is based on cross-section dataset covering the period between 2012 and 2014 for 28 Transition Countries. We employ both a probit model and the Oaxaca-Blinder decomposition methodology to investigate where there is a gender gap in innovation between female and male-owned firms. Our analysis is focused on the manufacturing sector characterized mainly by SMEs. SMEs in Transition Countries are far away from the technological frontier and have several ways to innovate. In these countries, the innovative activities of the firms could strengthen and be complementary to the existing ones. Besides bridging the technological gap, the innovative activity is the best possible strategy to be competitive and survive the increasing pressure of developed countries that have a comparative advantage especially in the production of high skill-intensive goods. The main finding of the probit model highlights that female owners have a significant and positive impact on the probability of introducing technological innovation in firms compared to maleowned firms. The well-acknowledged factors of innovation are confirmed: human capital, the sources of knowledge, the R\&D activities, and the access to external financial resources. In checking any regional effect, we have found that differently from European former-USSR Countries, the Eurasian former-USSR Countries present a significant and negative association with innovation.

In addition, results are of particular interest when employing the Oaxaca Blinder decomposition methodology. The existence of a gender gap in innovation is confirmed. In fact, we found that the innovation gap between female and male-owned firms is strongly significant. The plausible explanation is that this is mainly due to the differences in endowment effects. Among the intangible assets, human capital and sources of knowledge are the main factors that affect the innovation gap between the two groups of firms. Both human capital and job training contribute positively to this gap, while tertiary education has a negative effect. Also, R\&D activities and external knowledge contribute positively to the innovation differences. Concerning the tangible assets, the access to public subsidies has a significant and positive effect on the innovation gap. In contrast, the effect of the credit line appears to be significant and negative. The other tangible factors explain the other portion of the innovation gap.

The article is organized as follows: the next section provides the conceptual background in order to go deeply into the gender gap in innovation activities between female and male-owned firms. Section 3 describes the data and the variables. Section 4 outlines the econometric strategy, Sect. 5 presents and discusses the results. Finally, the last section provides discussion and conclusions. 


\section{Theoretical background}

So far, the role played by gender in innovation literature has not largely investigated. A substantial part of studies on innovation has not considered the participants in the innovation processes, believing that gender was a neutral determinant factor (Fagerberg et al., 2005) or that innovators were invisible (Belghiti-Mahut et al., 2016). Most of the innovation research at firm level has focused on the relationship between innovation and firms' performance (i.e., Latan et al., 2019; Wang \& Wang, 2012); the different types of innovation and firms' competitive advantage (i.e., Arranz et al., 2019; Bowonder et al., 2010); the determinants of innovation and firm growth (i.e., Fazlioğlu et al., 2019; Ahlin et al., 2014; Gupta et al., 2013; Aghion \& Howitt,1998). In the field of management and economics a growing literature has attempted to investigate the role of women in the firm highlighting: (i) the effect of women in the board of directors on the firm's financial and social performance (Boulouta, 2013; Carter et al., 2010; Solakoglu, 2013); (ii) the network effects among different boards whose directors are women (Hillman et al., 2007; Hodigere \& Bilimoria, 2015; Terjesen et al., 2009); (iii) the impact of women on corporate governance (Adams \& Ferreira, 2009); (iv) the female influence on the firms' acquisition decisions (Levi et al., 2015) and (v) the relationship between gender diversity in research and development (R\&D) team or management and organizational performance (Christiansen et al., 2017; Nakagawa, 2015; Smith et al., 2006; Triana et al., 2019; Wikhamn \& Wikhamn, 2019) or firm's innovation efficiency (Xie et al., 2020). According to the resource-based literature, a focus on the intangible resources such as employee composition in a firm rather than on tangible resources is essential to better understand a firm's innovative performance. Gender diversity, within a firm, can also be considered as a source of intangible resources (Ali et al., 2011). It, in fact, involves a difference in the knowledge base, experience, cognitive model, skills, educational background (Østergaard et al., 2011). Females in particular have both different perspectives to solve problems (QuintanaGarca \& Benavides-Velasco, 2008), and a greater ability to reduce board conflicts (Nielsen \& Huse, 2010). In addition, while a part of literature suggests that women tend to have better education and higher expectations of work (Eriksson-Zetterquist, 2007), other studies focusing on India and China point out that not only formal education, but also, in particular, training increases a firm's innovation performance (Naudè \& Rossouw, 2010; Goedhuys \& Sleuwaegen, 2000). Also, in transition economies of Eastern Europe and the Former Soviet Union investments in university education do not lead to improvements in the firm's innovation, as is the case with training (De Mel et al., 2009). Yet, open innovation literature highlights that gender diversity improves the external ties, increases the team knowledge, and generates new ideas (Diaz-Garcìa et al., 2013). Empirical studies conducted in industrialized and developing countries show a positive association between employee diversity in gender and firm innovation. In particular, for Danish manufacturing and service firms evidence shows that the most innovative firms have a more gender-balanced composition (Østergaard et al., 2011). Gender diversity in the organization and the difference in skills, knowledge and experience strongly support the team of Spanish firms operating in industrial and service sectors to be more innovative (Diaz-Garcìa et al., 2013) and the innovation 
activities are positively associated with the number of women employed in Colombian manufacturing firms (Gallego \& Gutierrez, 2018). All these studies show that the presence of women in teams increases the knowledge differences and the firm innovation performance mainly when it is combined with male entrepreneurship (Dai et al., 2019), while a firm size is weakly relevant when the analysis is focused on the relationship between gender and innovation (Teruel et al., 2015). The study of Ritter-Hayashi et al. (2019) is the only one that has recently examined the relationship between gender diversity and innovation comparing managers and owners both in developed and developing countries. Also, in this case, the authors show that female top managers as well as gender diversity among firm's owners promote a higher innovation firm activity. Overall, despite a large literature examining gender diversity, only few recent papers focus on the relationship between innovation and female top managers (Becic \& Vojinic, 2018; Dezso \& Ross, 2012) or analyze the difference between female managers and female owners (Dohse et al., 2019) showing mixed results. While the studies conducted by Becic and Vojinic (2018) on the relationship between female top manager and innovation in CEECS' firms show that, on average, firm innovation activities are lower when women are top managers, Dohse et al. (2019) focus on the role of female managers and female owners in the introduction of product innovation in emerging and developing countries showing that female owners rather than female managers are more prone to introduce innovation. Finally, focusing on the Transition Countries, few analyses attempt to explain the innovation gap between male and female owners at firm's level (Hozer-Kocmiel et al., 2017; Popovic Pantic, 2014; Sirec \& Mocnik, 2015). Although emphasizing the female capacity to improve incremental innovation, the study of Pantic (2014) is descriptive and relies on a sample of 22 Serbian small and medium firms. Also, Hozer-Kocmiel et al. (2017) examine the role of gender in innovation in SME in both tourism and creative sectors in five Baltic Sea countries and find that the creative industry is more innovative than the tourism sector, but their study is carried out on 102 qualitative pilot surveys on women who conducted their business activities during the year 2015. To the best of our knowledge, only Sirec and Mocnik (2015) examine the innovation activities and the gender dimensions of owner-managers of firms in eight South-Eastern European countries (SeECs) applying a binary logistic regression model. They show that significant relationships exist between the innovative activity and the main predictors (education, international orientation, and firm growth aspiration) that are different between the two genders. Notwithstanding this literature, evidence on the innovation gender gap in Transition Countries remains underestimated. In addition, our analysis is the first to employ the Blinder-Oaxaca decomposition to identify the factors responsible for the differences in the propensity to innovate between female and male-owned firms in 28 Transition Countries.

\section{Data collection and variables}

As noted above, we exploit firm-level data gathered from the Fifth Round of the Business Environment and Enterprise Performance Survey (BEEPS V) conducted in 2012-2014 jointly by the European Bank for Reconstruction and Development 
(EBRD) and the World Bank Group. The data of this firm-level survey was collected using face-to-face interviews with managers. The survey consists of 17 sections that provide several pieces of information on: (i) the innovation behavior of firms, (ii) innovative activities, organization practices, management and employees and (iii) other general information on firms. The survey covers a broad range of the non-agricultural economy including all manufacturing sectors, construction, services, transport, storage, communication and IT. The survey includes a representative sample of firms that have been chosen using the stratified sample methodology, these strata depending on the region, sector and dimension of the firm. BEEPS survey represents a unique opportunity that allows to analyze and compare factors that affect innovation for firms across transition countries. This survey allows us to also investigate the factors that influence the innovation activities across firms within a given country. It is based on data from about 17,000 firms from 32 countries of Eastern Europe and Central Asia. This group of countries shares a similar institutional background, in fact, all the countries considered, except for Turkey, have applied the principles of a centrally planned economy for several decades. According to their level of innovative activity it is possible to distinguish these countries in: (i) innovation followers and (ii) modest innovators (Tomaszewski \& Świadek, 2017). The sample used in our analysis consists of 5149 firms from 28 selected Transition Countries ${ }^{1}$ and 2097 firms that have adopted a technological innovation. These Transition economies have experienced an increase in their technological capabilities. In addition, these countries have introduced several policy measures to improve the level of competition and to make less concentrated market structures (Friesenbichler et al., 2014).

As dependent variable we employ a self-reported measure of innovation developed according to the Community Innovation Survey (CIS) (Brouwer \& Kleinknecht, 1996). In particular, we consider technological innovation defined as new or improved products (good or service) placed on the market, or the implementation of a new or improved production process within a firm. Therefore, based on information provided by the BEEPS survey, we construct our dependent variable, which is a binary variable equal to 1 if the firm, in the latest three years, has introduced a technological innovation, and 0 otherwise. The main explanatory variable of interest is the firm's ownership that assumes a value equal to 1 if the owner of the firm is female, and 0 if he is male. Using this variable in our estimation, we can verify whether female owners with respect to their male counterparts are more prone to adopt an innovation. Control variables are included in the analysis to account for other factors that are likely to influence firms' innovation activities. The impact of human capital can be captured if we consider: (i) the percentage of firm's permanent full-time workers holding a university degree; (ii) a dummy variable that shows if the firm has offered, during the previous year, formal training to its skilled workers and finally (iii) the years that the top manager spent in that specific sector. To consider firms' financial resources, we observe (i) the access to a line of credit or a loan from a financial institution and (ii) the receipt of financial subsidies from the national, regional or local governments or the European Union. We also include a binary variable for $R \& D$ which equals 1 if the firm, in the previous three years, has

1 The list of countries considered in our study is included in Table 5 in the Appendix. 
spent on research and development activities, or 0 otherwise. Since only a few firms are able to support their competitiveness and innovation by focusing exclusively on internal sources of knowledge, it is important to note the role played by knowledge from external sources. In this regard, we introduce a dummy variable equal to 1 if a firm, over the last three years, has used resources to purchase external knowledge from other businesses or organizations, or to 0 .

Other characteristics considered are: (i) size by means of an ordered variable that is equal to 1 for small firms (less than or equal to 19 employees), 2 for medium firms (20-99 employees) and 3 for large firms (more than 100 employees); (ii) the geographic market sales (iii) whether the firm is an independent economic entity (taking the value of 1 ) or part of a corporate group (taking 0 ).

To test whether ownership influences technological innovation, we exploit an ordinal categorical variable that takes into account how the firm was founded. To evaluate if female-intensity firms are more innovative, we include a variable that reflects the share of female workers in full-time employment. We also employ a sector variable; firms are aggregated according to the level of their technological intensity (high, medium and low-tech) using the Eurostat classification based on NACE Rev. 2 at 2-digit level. Finally, we divide our sample into four different geographical regions (European Former-USSR Countries, Former Yugoslavian Countries and Albania, Eurasian Former-USSR Countries and Central European countries) to check out the regional differences. Table 6 in the Appendix contains the variables included to account for factors that could affect the propensity of a firm to adopt an innovation. Table 1 reports the descriptive statistics.

Among the sampled firms $41 \%$ perform technological innovations and in $33 \%$ out of them the owner is female. On average, $36 \%$ of people working in the manufacturing sector are women, $32 \%$ of workforce holds a tertiary education diploma, while the industry-specific experience of managers is about 17 years. Job-training programs are offered to employees by $34 \%$ of sampled firms. $15 \%$ of firms spends in $\mathrm{R} \& \mathrm{D}$ activities and only $17 \%$ invests resources for the acquisition of external knowledge. Yet, $11 \%$ gains access to financial subsidies, while $35 \%$ of firms have the availability of a credit line. The data also show that only $9 \%$ of sampled firms is engaged in production of high skill-intensive goods and about $80 \%$ sells their products for the most part on the national markets. Finally, $79 \%$ are private firms and $80 \%$ is of small-medium size.

Table 2 displays the differences, in mean and proportions for all variables used in this analysis. To test if the differences are statistically significant, we perform the student's $t$-test ${ }^{2}$ used when two independent groups are compared.

We find a significant disadvantage of male owners in technological innovation activities so far as to offer formal training to its skilled workers and to obtain financial subsidies from the national, regional or local governments or the European Union. The findings also show significant differences between firms with female owners and those wholly male owned, in R\&D activities and in the acquisition of

\footnotetext{
2 Student's $t$-test is a parametric procedure that assumes normality of the data and equality of variances across comparison groups. This analysis is performed on log-transformed data and compares the means or proportions of the groups.
} 
external knowledge from other businesses or organizations. Finally, the only advantage that male owners have over their female counterparts can be seen above all in technology-intensive sectors.

To sum up, the difference in innovative activities between the firms with females amongst owners and those in which they are not present is strongly statistically significant, so we decide to perform the decomposition in order to understand: (i) the elements that could explain this gap and (ii) which one impacts more.

\section{Empirical strategy}

To identify gender innovation difference in transition countries, this paper employs an application of the Blinder (1973) and Oaxaca (1973) decomposition principle developed to investigate the source of gender wage gap. According to this decomposition, gender pay gap is the sum of: (i) the differences in the average observed characteristics of the two groups and (ii) the differences in the coefficient estimates. The linear Blinder-Oaxaca decomposition has been revised to be also applied to nonlinear estimation models (Bauer \& Sinning, 2008; Fairlie, 1999, 2005; Yun, 2000, 2004, 2005; Powers et al., 2009).

Therefore, we employ a multivariate nonlinear decomposition methodology to observe the contribution of each covariate to the difference in innovation between two groups: female-owned firms and male-owned ones in a sample of Transition Countries. This approach is an extension of the Blinder-Oaxaca technique developed by Powers et al. (2009) for non-linear dependent variables that allows us to examine differences not only between two groups but also between two points in time. The Oaxaca-Blinder approach and its extensions suggest employing the average of the estimated characteristics and coefficients in order to conduct the decomposition. This method requires different steps: (i) model specification and regression; (ii) decomposition of innovation gaps according to the Blinder-Oaxaca approach; (iii) the contribution of each explanatory variable $k$ on the total innovation gap between two groups according to the approach proposed by Yun (2004). For the two groups the probability to innovate can be estimated as follows:

$$
\mathrm{I}_{i j}=\Phi\left\lfloor X_{i j} \beta_{j}\right\rfloor
$$

$I_{i j}$ is the dependent variable, it is equal to 1 if a firm $i$ of the group $j(j=\mathrm{A}, \mathrm{B})$ has adopted a technological innovation, 0 otherwise. Note that the A stands for firms with female owners while B indicates firms with men owners.

$X_{i j}$ is the vector of the observed characteristics of the firm $i$ in a group $j$ and $\Phi($.) is the cumulative function of a normal distribution with zero mean and variance $\sigma^{2} .^{3}$ Using the maximum likelihood method, we estimate coefficients $\left(\beta_{j}\right)$ that allow us to calculate the predicted probability and determine the marginal effects representing the

\footnotetext{
${ }^{3}$ It should be highlighted that there may be unobserved heterogeneity in the characteristics of firms across groups and that this unobserved heterogeneity could influence the average probability of innovation. However, since we use cross-sectional data, the model does not allow to consider this phenomenon.
} 
Table 1 Descriptive statistics of variables

\begin{tabular}{|c|c|c|c|c|c|}
\hline Name of variable & Obs & Proportion & Mean & Std. Err & Std.Dev \\
\hline Technological innovation & 5028 & 0.41 & & 0.007 & \\
\hline Firm ownership & 5058 & 0.33 & & 0.007 & \\
\hline Firm dimension & 5149 & & & & \\
\hline Small firms & & 0.45 & & 0.007 & \\
\hline Medium firms & & 0.39 & & 0.007 & \\
\hline Large firms & & 0.15 & & 0.005 & \\
\hline Affiliation & 5149 & 0.07 & & 0.004 & \\
\hline \multicolumn{6}{|l|}{ Human capital } \\
\hline Education & 4812 & & 31.51 & & 28.59 \\
\hline Training programs & 5003 & 0.34 & & 0.007 & \\
\hline Experience top manager & 4930 & & 16.84 & & 10.26 \\
\hline \multicolumn{6}{|l|}{ Financial resources } \\
\hline Financial subsidies & 5009 & 0.11 & & 0.004 & \\
\hline Line of credit & 4997 & 0.35 & & 0.007 & \\
\hline Research and development & 5023 & 0.15 & & 0.005 & \\
\hline Knowledge & 3174 & 0.17 & & 0.007 & \\
\hline Sales market & 5019 & & & & \\
\hline More national sales & & 0.81 & & 0.005 & \\
\hline National and international sales & & 0.11 & & 0.004 & \\
\hline More international sales & & 0.08 & & 0.004 & \\
\hline Firm creation & 5108 & & & & \\
\hline Privatization of a state-owned firm & & 0.15 & & 0.005 & \\
\hline Originally private, from time of start up & & 0.79 & & 0.005 & \\
\hline Private subsidiary of a formerly state-owned firm & & 0.02 & & 0.002 & \\
\hline Joint venture with foreign partner(s) & & 0.02 & & 0.002 & \\
\hline State-owned firm & & 0.02 & & 0.002 & \\
\hline Female workers & 4168 & & 39.30 & & 29.30 \\
\hline \multicolumn{6}{|l|}{ Industry sectors } \\
\hline Low tech & 4761 & 0.46 & & 0.007 & \\
\hline Medium tech & & 0.45 & & 0.007 & \\
\hline High tech & & 0.09 & & 0.004 & \\
\hline \multicolumn{6}{|l|}{ Country regions } \\
\hline European former-USSR countries & 5058 & 0.40 & & 0.006 & \\
\hline Central European countries & & 0.14 & & 0.005 & \\
\hline Former Yugoslavian countries and Albania & & 0.16 & & 0.005 & \\
\hline Eurasian former- USSR countries & & 0.30 & & 0.006 & \\
\hline
\end{tabular}

change in predicted probability to innovate. To compute the difference in gender innovation and the main determinants that influence this gap, we assume, a priori, that the yields of firm characteristics are different depending on the male and female owners. The Oaxaca (1973) and Blinder (1973) approach and its extensions suggest employing the average of the estimated characteristics and coefficients in order to conduct 
Table 2 Overall sample characteristics

\begin{tabular}{|c|c|c|c|c|}
\hline \multirow[t]{2}{*}{ Variable } & \multirow[t]{2}{*}{ N.of Obs } & \multicolumn{3}{|c|}{ Overall sample } \\
\hline & & Men owners & Women owners & Differences \\
\hline Technological innovation & 5028 & 0.383 & 0.457 & $-0.074 * * *$ \\
\hline Small firms & 5058 & 0.459 & 0.460 & -0.001 \\
\hline Medium firms & 5058 & 0.395 & 0.386 & 0.009 \\
\hline Large firms & 5058 & 0.146 & 0.154 & -0.008 \\
\hline Female workers & 4104 & 4.609 & 4.610 & -0.001 \\
\hline Affiliation & 5058 & 0.070 & .071 & -.001 \\
\hline Education & 4812 & 4.858 & 4.857 & 0.001 \\
\hline Training programs & 5003 & 0.323 & 0.376 & $-0.053 * * *$ \\
\hline Experience top manager & 4930 & 4.775 & 4.761 & $-0.006^{* *}$ \\
\hline Financial subsidies & 5009 & 0.104 & 0.134 & $-0.030^{* * *}$ \\
\hline Line of credit & 4997 & 0.353 & 0.360 & -0.007 \\
\hline Research and development & 5023 & 0.134 & 0.169 & $-0.035 * * *$ \\
\hline Knowledge & 3174 & 0.164 & 0.168 & -0.004 \\
\hline More National sales & 5019 & 0.815 & 0.0808 & 0.009 \\
\hline National and International sales & 5019 & 0.107 & 0.106 & 0.001 \\
\hline More International sales & 5019 & 0.075 & 0.086 & -0.011 \\
\hline Privatization of a state-owned firm & 5020 & 0.123 & 0.194 & $-0.071 * * *$ \\
\hline Originally private, from time of start up & 5020 & 0.820 & 0.738 & $0.082 * * *$ \\
\hline $\begin{array}{l}\text { Private subsidiary of a formerly state-owned } \\
\text { firm }\end{array}$ & 5020 & 0.021 & 0.027 & -0.006 \\
\hline Joint venture with foreign partner(s) & 5020 & 0.023 & 0.016 & 0.007 \\
\hline State-owned firm & 5020 & 0.011 & 0.026 & $-0.015 * * *$ \\
\hline Low tech & 4761 & 0.428 & 0.540 & $-0.112 * * *$ \\
\hline Medium tech & 4761 & 0.477 & 0.389 & $0.088 * * *$ \\
\hline High tech & 4761 & 0.095 & 0.071 & $0.024 * * *$ \\
\hline European former-USSR countries & 5058 & 0.405 & 0.401 & 0.004 \\
\hline Central European countries & 5058 & 0.127 & 0.172 & $-0.045 * * *$ \\
\hline Former Yugoslavian countries and Albania & 5058 & 0.164 & 0.141 & $0.023 * *$ \\
\hline Eurasian Former- USSR countries & 5058 & 0.305 & 0.207 & 0.018 \\
\hline $\mathrm{N}$ & & 3362 & 1666 & \\
\hline
\end{tabular}

Mean and proportions for continuous and dummy variables, respectively

*Statistically significant at $10 \%$ level, based on two-tailed t-tests

$* * 5 \%$ level, based on two-tailed t-tests

*** $1 \%$ level, based on two-tailed t-tests

the decomposition. Therefore, the difference in the average probability of innovation between two groups of interest is the sum of two components:

$$
I_{A}-I_{B}=\left[\overline{\Phi\left(X_{A} \hat{\beta}_{A}\right)}-\Phi \overline{\left(X_{B} \hat{\beta}_{A}\right)}\right\rfloor+\left[\overline{\Phi\left(X_{B} \hat{\beta}_{A}\right)}-\Phi \overline{\left(X_{B} \hat{\beta}_{B}\right)}\right\rfloor=\operatorname{Exp}+N \operatorname{Exp}
$$


The right-hand side term defines differences in the average predicted probabilities of the two types of firm to adopt a technological innovation that result from differences in their relative characteristics. The average predicted probabilities for each group are estimated at all values of their characteristics and the differences are weighted by group A' estimated coefficients $\left(\hat{\beta}_{A}\right)$. This component $(\operatorname{Exp})$ indicates the portion of the innovation gap deriving from differences in the observed characteristics of the two groups. The second one (NExp) defines differences between the estimated coefficients of the two groups weighted by the characteristics of group B $\left(X_{B}\right)$. This term reflects the unmeasured portion of the innovation gap, and for this reason, it is also known as the "unexplained" element of the decomposition.

According to Even and Macpherson $(1990,1993)$ the contribution of an explanatory variable $\mathrm{k}$ in the $\operatorname{Exp}$ component is given by:

$$
\operatorname{Exp}_{k}=\left\lfloor\overline{\Phi\left(X_{A} \hat{\beta}_{B}\right)}-\Phi \overline{\left(X_{B} \hat{\beta}_{B}\right)}\right]\left[\frac{\left(\bar{X}_{A}^{k}-\bar{X}_{B}^{k}\right) \hat{\beta}_{A}^{k}}{\left(\bar{X}_{A}-\bar{X}_{B}\right) \hat{\beta}_{A}}\right]
$$

where $\bar{X}_{j}^{k}$ is the mean of the observations of variable k in the group $j$.

A generalization of this result is proposed by Yun (2004) to measure the contribution of a variable $\mathrm{k}$ to the total innovation gap between groups $\mathrm{A}$ and $\mathrm{B}$. Thus, the innovation gap between two groups can be decomposed as follows:

where

$$
I_{A}-I_{B}=\sum_{k=1}^{K} W_{\Delta X}^{k}\left[\overline{\Phi\left(X_{A} \hat{\beta}_{A}\right)}-\Phi \overline{\left(X_{B} \hat{\beta}_{A}\right)}\right]+\sum_{k=1}^{K} W_{\Delta \bar{\beta}}^{k}\left[\overline{\Phi\left(X_{B} \hat{\beta}_{A}\right)}-\Phi \overline{\left(X_{B} \hat{\beta}_{B}\right)}\right],
$$

$$
W_{\Delta X}^{k}=\left[\frac{\left(\bar{X}_{A}^{k}-\bar{X}_{B}^{k}\right) \hat{\beta}_{A}^{k}}{\left(\bar{X}_{A}-\bar{X}_{B}\right) \hat{\beta}_{A}}\right], W_{\Delta \bar{\beta}}^{k}=\frac{\bar{X}_{B}^{k}\left(\hat{\beta}_{A}^{k}-\hat{\beta}_{B}^{k}\right)}{X_{B}\left(\hat{\beta}_{A}-\hat{\beta}_{B}\right)} \text {, and } \sum_{k=1}^{K} W_{\Delta X}^{k}=\sum_{k=1}^{K} W_{\Delta \bar{\beta}}^{k}=1
$$

Lastly, it is possible to test the statistical significance of the effects of coefficients and characteristics using the delta method proposed by Yun (2005). In fact:

$$
C_{k}=W_{\Delta X}^{k} \overline{\Phi\left(X_{A} \hat{\beta}_{A}\right)}-\Phi\left(\overline{X_{B} \hat{\beta}_{A}}\right) a n d D_{k}=W_{A \widetilde{B}}^{k} \sum_{1}^{K} W_{\Delta \bar{\beta}}^{k} \overline{\Phi\left(X_{B} \hat{\beta}_{A}\right)}-\Phi \overline{\left(X_{B} \hat{\beta}_{B}\right)}
$$

It represents the effects of the characteristics and coefficients of the variable $k$, respectively. For $C_{k}$ and $D_{k}$ the asymptotic variances are:

$$
\sigma_{C_{k}}^{2}=\frac{\partial C_{k}}{\partial \beta_{A}^{\prime}} \sum\left(\beta_{A}\right) \frac{\partial C_{k}^{\prime}}{\partial \beta_{A}} \text { and } \sigma_{D_{k}}^{2}=\frac{\partial D_{k}}{\partial \beta_{A}^{\prime}} \sum\left(\beta_{A}\right) \frac{\partial D_{k}^{\prime}}{\partial \beta_{A}}+\frac{\partial D_{k}}{\partial \beta_{B}^{\prime}} \sum\left(\beta_{B}\right) \frac{\partial D_{k}^{\prime}}{\partial \beta_{B}}
$$

where $\frac{\partial C_{k}}{\partial \beta_{j}^{\prime}}$ and $\frac{\partial D_{k}}{\partial \beta_{j}^{\prime}}$ are gradient vectors of order $(1 \times K)$ and $\sum\left(\beta_{j}\right)$ is the asymptotic covariance matrix of $\beta$ for the group $j$.

This matrix is obtained by the probit model regression. Yun (2005) shows that under the null hypothesis of nullity of the coefficients of the variable $\mathrm{k}$, namely 
$C_{k}=0$ and $D_{k}=0$, the statistical tests $t_{c_{k}}=\frac{C_{k}}{\sigma_{C_{k}}}$ and $t_{c_{k}}=\frac{D_{k}}{\sigma_{D_{k}}}$ are distributed according to the normal distribution.

\section{Econometric results}

First, we examine the factors that affect firms' innovation employing a probit model that allows us to identify the determinants of a firm's decision to innovate. Needless to say, we have chosen a probit model because the dependent variable is dichotomous and it also represents the starting point for the decomposition allowing, in advance, to highlight the determinants of innovation activities. Then, we conduct the multivariate decomposition methodology to explain the gender innovation gap in Transition Countries. This approach distinguishes the innovation differences between enterprises with female and male owners into a part that accounts for the disparities of observed covariates and a part that cannot be explained by observed disparities in the covariates. Table 3 displays the results of the probit model. The table reports both coefficients and marginal effects.

The main findings confirm the role of gender ownership on a firm's propensity to innovate. Firms with female owners are more likely to introduce technological innovation. This means that if firms have females among their owners, they could lead to an increase in innovation more than 3\% compared to male-owned firms. Therefore, this result is consistent with other studies (Hayashi et al., 2019; Nielsen \& Huse, 2010; Quintana-Garca \& Benavides-Velasco, 2008) which show that a diversified gender composition of ownership can improve firm innovation performance since women and men have different skills, know-how, and experience in solving problems. These factors when combined and used in the best way, can result in new innovative ideas (Dai et al., 2019). Diversity between workers is also crucial. The presence of female employees and managers has a positive and significant effect on firm's innovation. In this regard, a $1 \%$ increase in female workers leads to a $7 \%$ increase in innovation. The female employees and managers in the firm should increase the interaction between different types of knowledge and skills with a consequent growth of the firm's knowledge base for an innovative activity.

Moving on to the human capital, both education and firms' training programs have a positive effect on the decision to adopt a technological innovation, but they differ in magnitude. With respect to education, ${ }^{4}$ our findings reveal that an increase of one percentage point in the tertiary-educated workers produces a modest increase equal to $0.1 \%$ of the probability to innovate since education improves technical expertise, promotes creativity, and facilitates the use of tools and equipment, while firms whose employees receive training programs have $8 \%$ of chance of implementing innovation. This means that training programs provide workers with the skills needed to enhance the firms' innovative capacity (Naudè and Rossouw, 2010;

\footnotetext{
${ }^{4}$ Our database does not contain information on the level of education of the female entrepreneur, nor on her experience or other variables that could be proxies for education. However, we believe that this bias, if any, could be the same for men. Furthermore, we also believe that controlling for firm sector may get some of the information related to education. We are aware that this is a weakness of the paper.
} 
Goedhuys \& Sleuwaegen, 2000). Moreover, a top manager with experience has a positive effect on the propensity to innovate. By increasing their years of experience, the top manager strengthens his innovation capabilities. It follows that, for each additional year of experience, the innovative capacity of the firm increases by $0.2 \%$.

When considering the firm size, we find that large and medium firms show a significant and negative impact on innovation performance even if larger firms plausibly may have a higher gender diversity potential. As regards the variable that captures the ownership status of firms, we can remark that private firms have a $6.8 \%$ propensity to influence innovation activities compared to firms set up as a result of state-owned firm privatization. Then, the plausible interpretation is that the State's influence on public firms is still crucial in our sample countries and the firms' privatization process is not yet completed.

Our findings also confirm that firms' external financial resources are significant for the firm performance to fund artefacts, prototypes, and patents. Firms receiving financial subsidies are $9 \%$ more responsive to adopt an innovation than those without any kind of subsidy. Our findings suggest that public subsidies have additional effects on firms' innovation activities with respect to private funding. Among them, the access to a line of credit gives firms an innovation probability of more than $4 \%$ with respect to those that do not have this access. This implies that, despite financial constraints and restrictions, it is easier for the firms to obtain a line of credit or a loan from a financial institution.

Needless to say, R\&D activities are strongly significant and positively related to the probability of introducing firms' innovation. The chance of innovating for firms that invest in $R \& D$ is $23 \%$ more responsive than those which prefer not to allocate resources to in-house or external R\&D activities. Another source of innovation is the acquisition of external knowledge from other firms, university, and research institutes. Firms that gain external experience and knowledge are $11.8 \%$ more subject to innovate than those that have not focused on the acquisition of external knowledge. It follows that external knowledge is an additional and complementary input for the development and improvement of the firms' innovation activities.

Moving on to the geographical area where the firms trade their products, our findings show that firms selling more on the international markets are $11.5 \%$ less likely to have innovation, as against firms that sell mainly on national markets. This would suggest that the exporting firms are less competitive on the international market.

With reference to the Country Regions, the probability of developing innovation decreases significantly (18\%) only for Eurasian former-USSR Countries if compared to European former-USSR Countries. Probably the result depends on the innovation policies adopted in this geographical area that has been engaged in a long-run transition process passing from a planned economic system to a market economy. In addition, to control the heterogeneity across regions considered in our analysis, we have run the baseline model adding the interactions between regions and gender firm's ownership. This further estimation shows that there are not statistically significant differences across regions. This result is also confirmed by the joint F-test on interaction effects.

Table 4 displays the results obtained using the extension of the Oaxaca-Blinder method developed by Powers et al. (2009). In particular, it shows the contribution of 


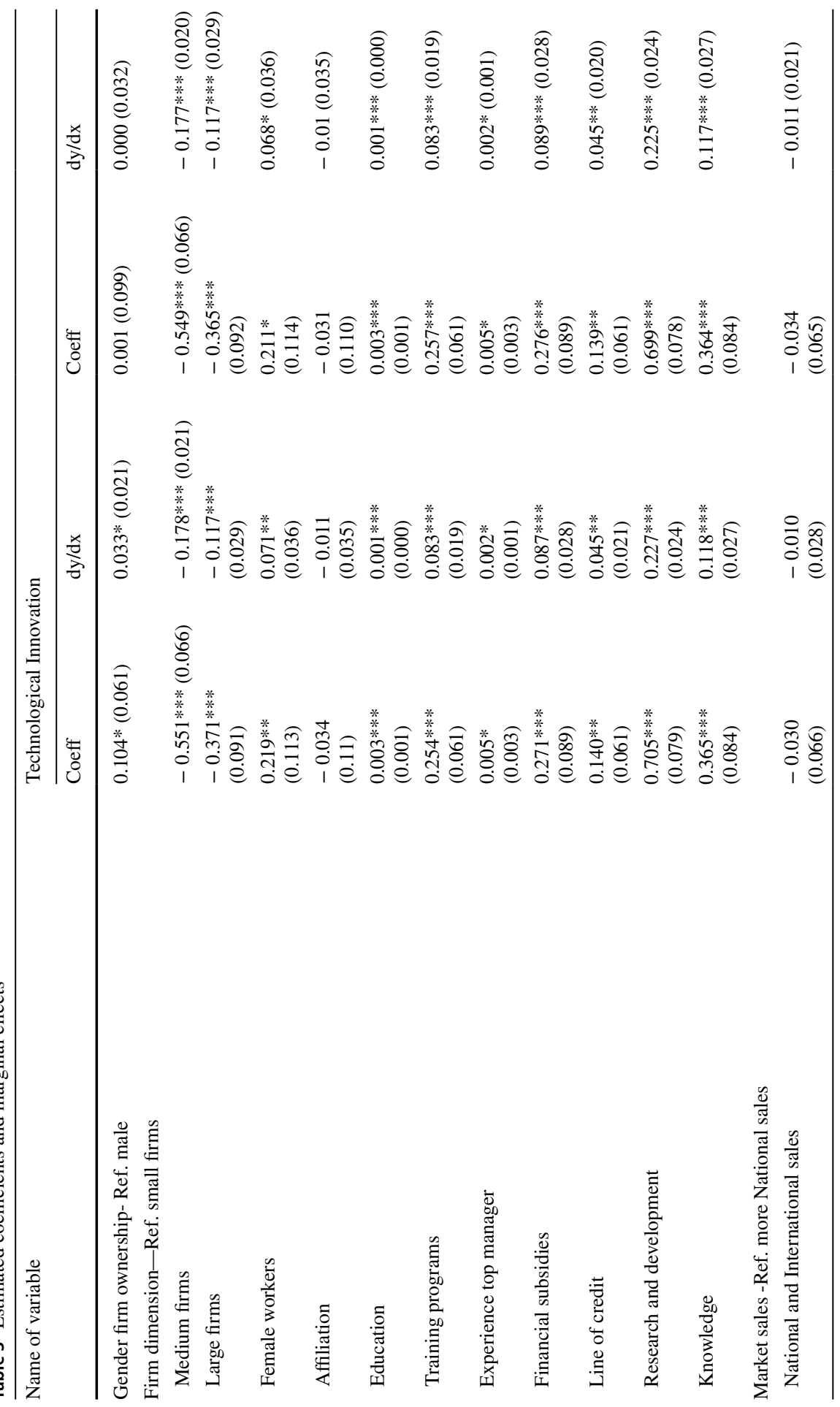




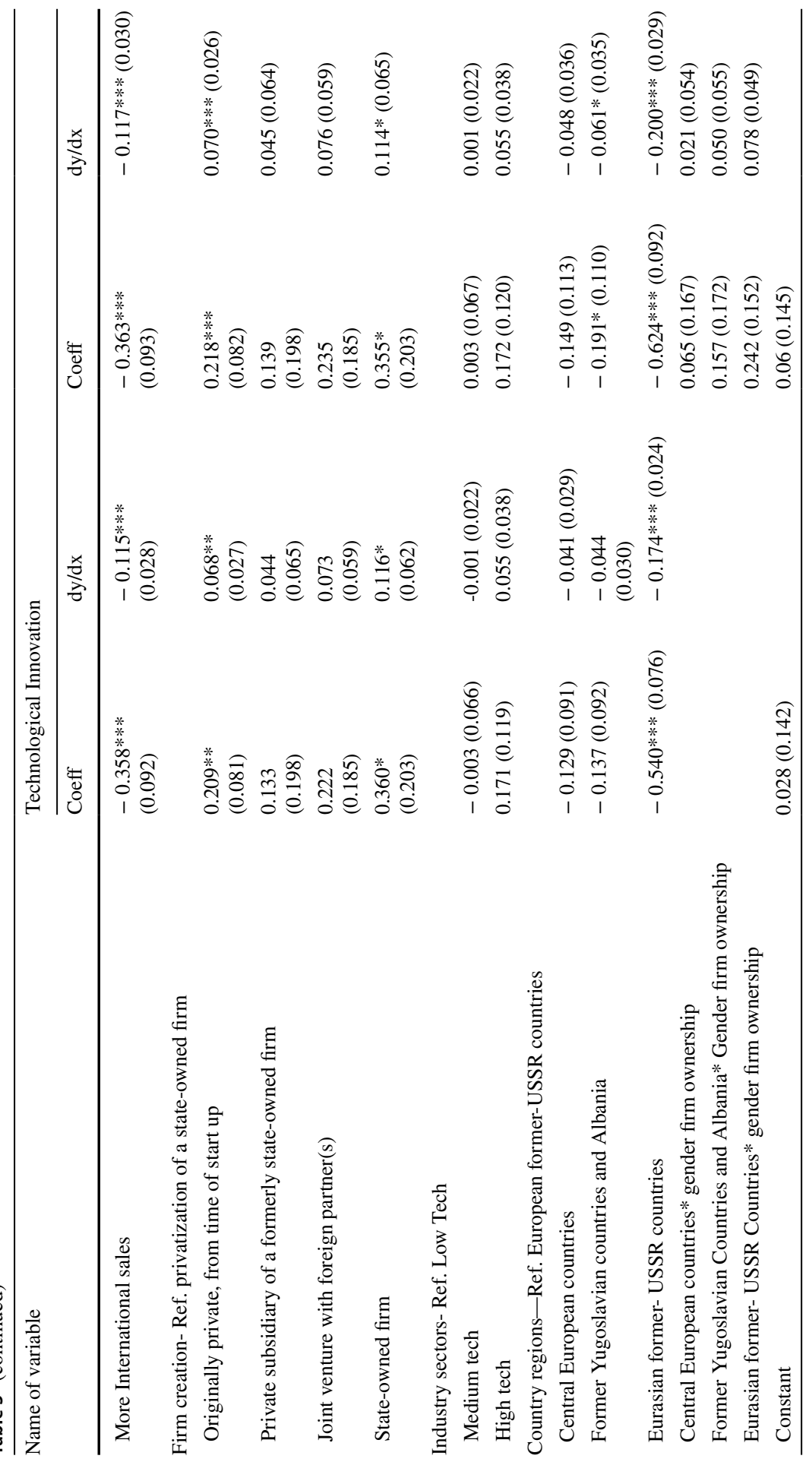




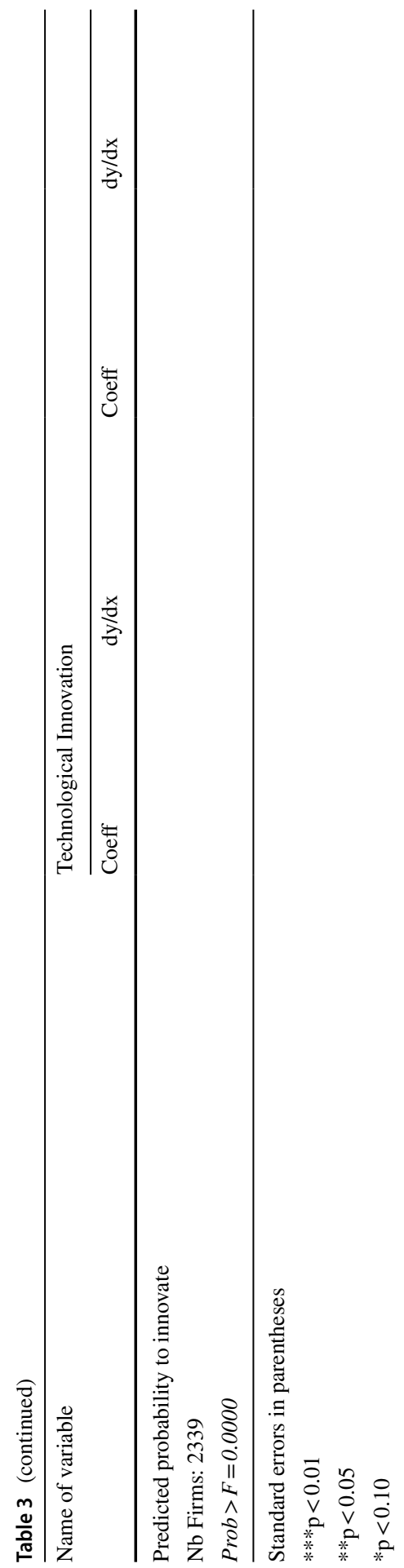


endowment and coefficient effects in explaining the innovation gap between enterprises with female and male owners. A negative (positive) contribution indicates that the determinant was narrowing (increasing) the gap between the two groups. First, the innovation gap between the two categories of firms is the sum of the aggregate effect of endowments and coefficients. As shown in Table 4, the gap in technological innovation between the two groups examined is strongly significant and equal to $5.7 \%$. The overall contribution of the endowment effects (or observed characteristics) is statistically significant and account for a sizeable portion of the total gap. In fact, about $43 \%$ of this innovation gap is attributable to the differences in endowment effects. That is, differences in observed characteristics play a crucial role in explaining this gap. Although not statistically significant, the other $57 \%$ of the disparities in technological innovation is due to the effect of coefficients (or unexplained factors). This means that these differences cannot be easily described because the reason for this change in coefficients is unknown. In addition, the unexplained fraction could also be a result of factors that are not directly observable.

This result assumes that if the differences in the characteristics of female and male-owned firms were to disappear, the innovation gap observed would be narrowed to $2.4 \%$. The gap in innovation can be attributed mainly to the human capital and sources of knowledge that represent $11.45 \%$ and $16.35 \%$ of endowment effect, respectively.

The different sources of human capital impact in the opposite way on the innovation gap. The on-the-job training programs contribute to this gap with a share of $12 \%$. In other words, if the firms of two groups provided the same training to their workers the difference in innovation could be down by $0.7 \%$. At the same time, an increase in the innovation gap could be experienced equalizing the percentage of permanent full-time workers with a university degree in the firms with female owners and those wholly male-owned. In other words, it seems that the innovation gap is related to the training programs rather than to education (De Mel et al., 2009), that in these countries is generally high for both men and women. R\&D expenditure and external knowledge jointly influence the innovation gap between the two groups. This means that if the firms allocated an equal amount of resources to R\&D and purchased knowledge from other businesses or organizations the difference in innovation would reduce by $0.8 \%$ and $0.1 \%$, respectively. In fact, since women are more cooperative than men and therefore more likely to create ties with external organizations (Jackson et al, 2003), it is plausible to assume that firms with a high share of women in R\&D teams are more oriented to introduce innovation (Diaz_Garcia et al., 2013).

The access to financial resources has a different effect on the innovation gap. The access to the financial subsidies explains the innovation differential of $3.25 \%$. This finding reveals that if the firms with male owners enjoyed the same financial subsidies as the enterprises with female owners the gap in the probability of innovating could be reduced by $0.2 \%$. In contrast, the effect of characteristic associated with availability of a credit line is significant and negative. It follows that the gap in innovation could increase significantly by $0.1 \%$ if the two types of firms had access to these financial funds. When we look at firm characteristics, we find that firm size accounts for nearly $3 \%$ of the explained in innovation differential. In particular, 
small firms account for $1.89 \%$ of the gap, meaning that this effect is greater in these firms.

Moving on to the process of setting up a firm and to the geographical scope of the market, since at the aggregate level the effect of the endowments is not significant, we focus our attention only on firms that have been privatized and those that sell more on the national market. For both types of firms, the variation in term of endowments is significant and negative. Thus, both encourage a reduction in the gap observed. Finally, going back to the areas where firms undertake their activities, we find that firms established in the former Eurasian region boost a significant increase of the innovation gap between the two types of firms equal to $0.1 \%$.

\section{Discussion and final remarks}

The aim of the paper was to investigate the effect of gender ownership on technological innovation at the firm level and highlight the factors that explain the gender ownership gap in innovativeness for selected transition countries.

Employing a Probit model, we have first examined the factors that affect firm's innovation. Then, we have applied the extension of the Oaxaca-Blinder decomposition methodology developed by Powers et al. (2009) to investigate the gender innovation gap between female and male-owned firms. The decomposition results confirm some findings obtained by the probit model. The intangible assets as human capital and sources of knowledge are the main factors that affect the innovation gap between the two groups of firms.

Among the factors that account for the human capital, job training activities contribute positively to this gap while tertiary education has negative effects. Thus, the difference in human capital is plausibly due to training programs provided to the employees rather than on their level of education. Moving to the sources of knowledge, both R\&D activities and external knowledge contribute positively to the innovation difference. Another feature that could explain the gap observed is the access to financial resources, namely the tangible assets of a firm. In more detail, the access to subsidies widens the gap, on the other hand, the availability of a credit line reduces it. Geographical factors and firm size explain another portion of the innovation gap.

Therefore, firms should continuously promote training programs at all levels to increase worker participation in the strategic decisions of firms and should give priority to the recruitment of workers with a high level of education; in this way firms could build capabilities in support of innovation activity.

With regard to the sources of knowledge for innovation, firms should aim to improve internal knowledge to make better use of external knowledge. The acquisition of external knowledge could be useful to a firm if and only if it has an existing base of knowledge that enables it to use it. Hence, firms should implement/support policies and programs focusing on the development of an internal knowledge base for the optimal use of both types of knowledge. 
Table 4 Probit decomposition of technological innovation gap

\begin{tabular}{|c|c|c|c|c|}
\hline Technological Innovation & Estimate & & Std.Err & Percent \\
\hline Explained: due to the difference in characteristics & $0.024 * * *$ & & $(0.009)$ & 42.53 \\
\hline Unexplained: due to the difference in coefficients & 0.033 & & $(0.021)$ & 57.47 \\
\hline Raw difference & $0.057 * * *$ & & $(0.019)$ & \\
\hline \multicolumn{5}{|l|}{ Due to difference in characteristics (E) } \\
\hline Human capital & & & & 11.45 \\
\hline Education & $-0.001 * * *$ & & $(0.000)$ & -1.56 \\
\hline Top manager experience & 0.001 & & $(0.001)$ & 0.99 \\
\hline Program training & $0.007 * * *$ & & $(0.002)$ & 12.02 \\
\hline Sources of knowledge & & & & 16.35 \\
\hline Research \& development & $0.008 * * *$ & & $(0.002)$ & 14.65 \\
\hline Knowledge & $0.001 *$ & & $(0.001)$ & 1.70 \\
\hline Financial resources & & & & 1.63 \\
\hline Financial subsidies & $0.002 * *$ & & $(0.001)$ & 3.25 \\
\hline Line of credit & $-0.001^{* *}$ & & $(0.000)$ & -1.62 \\
\hline Affiliation & 0.000 & & $(0.000)$ & 0.42 \\
\hline Female workers & 0.009 & & $(0.007)$ & 15.57 \\
\hline Firm dimension & & & & 2.91 \\
\hline Small firms & $0.001 * * *$ & & $(0.000)$ & 1.89 \\
\hline Medium firms & $0.000^{* *}$ & & $(0.000)$ & 0.87 \\
\hline Large firms & 0.000 & & $(0.000)$ & 0.15 \\
\hline Firm creation & & & & -3.43 \\
\hline Privatization of a state-owned firm & $-0.007^{*}$ & & -0.003 & -11.71 \\
\hline Originally private, from time of start up & 0.001 & & $(0.004)$ & 1.25 \\
\hline Private subsidiary of a formerly state-owned firm & 0.000 & & $(0.001)$ & 0.86 \\
\hline Joint venture with foreign partner(s) & 0.001 & & $(0.001)$ & 2.40 \\
\hline State-owned firm & 0.002 & & $(0.001)$ & 3.77 \\
\hline Market sales & & & & -3.36 \\
\hline More National sales & $-0.001 * * *$ & & $(0.000)$ & -2.43 \\
\hline National and International sales & 0.000 & & $(0.000)$ & 0.40 \\
\hline More International sales & -0.001 & & $(0.001)$ & -1.33 \\
\hline Industry sector & & & & -1.63 \\
\hline Low tech & 0.000 & & $(0.003)$ & 0.83 \\
\hline Medium tech & -0.002 & & $(0.002)$ & -4.32 \\
\hline High tech & 0.001 & & $(0.001)$ & 1.86 \\
\hline Country region & & & & 2.63 \\
\hline European former-USSR countries & -0.001 & & $(0.001)$ & -1.61 \\
\hline Central European countries & 0.001 & & $(0.002)$ & 2.60 \\
\hline Former Yugoslavian countries and Albania & -0.000 & & $(0.000)$ & -0.62 \\
\hline Eurasian former- USSR countries & $0.001 * * *$ & & $(0.000)$ & 2.26 \\
\hline \multicolumn{5}{|l|}{ Due to difference in coefficients $(\mathrm{C})$} \\
\hline Human capital & & & & 86.79 \\
\hline Education & 0.055 & $(0.037)$ & & 95.46 \\
\hline
\end{tabular}


Table 4 (continued)

\begin{tabular}{|c|c|c|c|}
\hline Technological Innovation & Estimate & Std.Err & Percent \\
\hline Top manager experience & -0.022 & $(0.048)$ & -39.14 \\
\hline Program training & 0.017 & $(0.023)$ & 30.47 \\
\hline Sources of knowledge & & & -56.02 \\
\hline Research \& development & -0.014 & $(0.019)$ & -25.20 \\
\hline Knowledge & -0.018 & $(0.015)$ & -30.82 \\
\hline Financial resources & & & 55.48 \\
\hline Financial subsidies & 0.004 & $(0.011)$ & 6.52 \\
\hline Line of credit & 0.028 & $(0.027)$ & 48.96 \\
\hline Affiliation & -0.010 & $(0.009)$ & -17.26 \\
\hline Female workers & 0.002 & $(0.038)$ & 2.96 \\
\hline Firm dimension & & & 22.82 \\
\hline Small firms & -0.013 & $(0.016)$ & -22.50 \\
\hline Medium firms & 0.034 & $(0.021)$ & 58.82 \\
\hline Large firms & -0.008 & $(0.011)$ & -13.50 \\
\hline Firm creation & & & -98.07 \\
\hline Privatization of a state-owned firm & -0.009 & $(0.011)$ & -15.11 \\
\hline Originally private, from time of start up & -0.046 & $(0.060)$ & -80.39 \\
\hline Private subsidiary of a formerly state-owned firm & 0.004 & $(0.003)$ & 7.00 \\
\hline Joint venture with foreign partner(s) & -0.008 & $(0.006)$ & -14.42 \\
\hline State-owned firm & 0.003 & $(0.002)$ & 4.85 \\
\hline Market sales & & & -30.05 \\
\hline More National sales & -0.017 & $(0.016)$ & -29.03 \\
\hline National and International sales & -0.012 & $(0.009)$ & -21.18 \\
\hline More International sales & 0.012 & $(0.008)$ & 20.16 \\
\hline Industry sector & & & 97.63 \\
\hline Low tech & 0.020 & $(0.023)$ & 34.88 \\
\hline Medium tech & -0.012 & $(0.009)$ & 88.40 \\
\hline High tech & 0.012 & $(0.008)$ & -25.65 \\
\hline Country region & & & -20.33 \\
\hline European former-USSR countries & -0.029 & $(0.021)$ & -49.14 \\
\hline Central European countries & 0.001 & $(0.009)$ & 1.15 \\
\hline Former Yugoslavian countries and Albania & 0.004 & $(0.011)$ & 6.98 \\
\hline Eurasian former- USSR countries & 0.012 & $(0.014)$ & 20.68 \\
\hline
\end{tabular}

Total observations is 5058

Standard errors in parentheses

$* * * \mathrm{p}<0.01$

$* * \mathrm{p}<0.05$

$* \mathrm{p}<0.10$

Also, the lack of access to finances is a mechanism that generates large disparities between firms; an action by the institutions seems crucial. Governments should define effective policies to remove barriers for expanding the access 
to financial resources. And above all, small firms have to face problems when approaching to providers of finance in order to require funds to support innovation activities. In fact, it is difficult to finance innovation activities due to the imperfections in the capital market which occur mainly in emerging countries where the capital market is less mature with respect to the developed market countries.

To conclude, although based on cross-sectional datasets, our analysis has highlighted a significant innovation gap between the two groups of firms in a sample of transition countries. Broadly speaking, some tangible and intangible assets appear to have triggered the technological innovation gap in the firms where a diversified gender composition of the ownership prevails. These are relevant results since they point out that in the period 2012-2014 the public decision-makers had a substantial role to finance firms with subsidies, and firms implemented investment in human capital and source of knowledge. These firms have improved their innovation performance by filling the innovation gap.

\section{Appendix}

See Tables 5 and 6.

Table 5 List of countries

\begin{tabular}{llll}
\hline Albania & Czech Republic & Kyrgyzstan & Russia \\
Armenia & Estonia & Lithuania & Serbia \\
Azerbaijan & North Macedonia & Latvia & Slovakia \\
Belarus & Georgia & Moldova & Slovenia \\
Bosnia-Herzegovina & Hungary & Montenegro & Tajikistan \\
Bulgaria & Kazakhstan & Poland & Ukraine \\
Croatia & Kosovo & Romania & Uzbekistan \\
\hline
\end{tabular}


Table 6 Description of variables

\begin{tabular}{|c|c|}
\hline Variable & Description \\
\hline Technological innovation & $\begin{array}{l}1 \text { if firm, in the last three years, has introduced a techno- } \\
\text { logical innovation, } 0 \text { otherwise }\end{array}$ \\
\hline Firm ownership & $\begin{array}{l}1 \text { if the firm has female owners, } 0 \text { if firm ownership is } \\
\text { exclusively male }\end{array}$ \\
\hline \multicolumn{2}{|l|}{ Firm dimension } \\
\hline Small firms & 1 if a firm has $<=19$ employees \\
\hline Medium firms & 2 if a firm has $>=20$ and $<=99$ \\
\hline Large firms & 3 if a firm has $>=100$ \\
\hline \multicolumn{2}{|l|}{ Firm creation } \\
\hline & 1 Privatization of a state-owned firm \\
\hline & 2 Originally private, from time of start up \\
\hline & 3 Private subsidiary of a formerly state-owned firm \\
\hline & 4 Joint venture with foreign partner(s) \\
\hline & 5 State-owned firm \\
\hline Affiliation & 1 if a firm is part of larger firm, 0 otherwise \\
\hline Female workers & $\begin{array}{l}\text { Percentage of the permanent full-time female workers } \\
\text { (employees and managers) within the firm }\end{array}$ \\
\hline \multicolumn{2}{|l|}{ Human capital } \\
\hline Education & $\begin{array}{l}\text { Percentage of the permanent full-time workforce (employ- } \\
\text { ees and managers) holding a university degree }\end{array}$ \\
\hline Training programs & $\begin{array}{l}1 \text { if a company, in the fiscal year, has formal training } \\
\text { programs its employees, } 0 \text { otherwise }\end{array}$ \\
\hline Experience top manager & $\begin{array}{l}\text { Years of experience working in the sector of the top } \\
\text { manager }\end{array}$ \\
\hline \multicolumn{2}{|l|}{ Financial resources } \\
\hline Financial subsidies & $\begin{array}{l}1 \text { if a firm, in the last three years, has received any subsi- } \\
\text { dies from the national, regional or local governments or } \\
\text { European Union sources, } 0 \text { otherwise }\end{array}$ \\
\hline Line of credit & $\begin{array}{l}1 \text { if a firm, in the fiscal year, have a line of credit or a loan } \\
\text { from a financial institution, } 0 \text { otherwise }\end{array}$ \\
\hline Research and development & $\begin{array}{l}1 \text { if a firm, during the last three years, has spent on R\&D } \\
\text { activities, either in-house or contracted with other com- } \\
\text { panies, } 0 \text { otherwise }\end{array}$ \\
\hline Knowledge & $\begin{array}{l}1 \text { if a firm, during the last three years, has spent on the } \\
\text { acquisition of external knowledge, } 0 \text { otherwise }\end{array}$ \\
\hline \multicolumn{2}{|l|}{ Market sales } \\
\hline More national sales & $\begin{array}{l}1 \text { if a firm, in the fiscal year, sold its products more in } \\
\text { national market }\end{array}$ \\
\hline National and International sales & $\begin{array}{l}2 \text { if a firm, in the fiscal year, sold its products both in } \\
\text { national and international market }\end{array}$ \\
\hline More International sales & $\begin{array}{l}3 \text { if a firm, in the fiscal year, sold its products more in } \\
\text { international market }\end{array}$ \\
\hline \multicolumn{2}{|l|}{ Industry sectors } \\
\hline Low tech & 1 if a firm is a part of low-tech sector \\
\hline Medium tech & 2 if a firm is a part of medium tech sector \\
\hline High tech & 3 if a firm is a part of high-tech sector \\
\hline
\end{tabular}


Table 6 (continued)

\begin{tabular}{ll}
\hline Variable & Description \\
\hline Country regions & \\
European former-USSR countries & 1 for European Former-USSR Countries \\
Central European countries & 2 for Central European Countries \\
Former Yugoslavian countries and Albania & 3 for Former Yugoslavian Countries and Albania \\
Eurasian former-USSR countries & 4 for Eurasian Former- USSR Countries \\
\hline
\end{tabular}

Funding Open access funding provided by Università Cattolica del Sacro Cuore within the CRUI-CARE Agreement.

Open Access This article is licensed under a Creative Commons Attribution 4.0 International License, which permits use, sharing, adaptation, distribution and reproduction in any medium or format, as long as you give appropriate credit to the original author(s) and the source, provide a link to the Creative Commons licence, and indicate if changes were made. The images or other third party material in this article are included in the article's Creative Commons licence, unless indicated otherwise in a credit line to the material. If material is not included in the article's Creative Commons licence and your intended use is not permitted by statutory regulation or exceeds the permitted use, you will need to obtain permission directly from the copyright holder. To view a copy of this licence, visit http://creativecommons.org/ licenses/by/4.0/.

\section{References}

Adams, R. B., \& Ferreira, D. (2009). Women in the boardroom and their impact on governance and performance. Journal of Financial Economics, 94(2), 291-309.

Aghion, P., \& Howitt, P. (1998). Capital accumulation and Innovation as Complementary Factor in LongRun Growth. Journal of Economic Growth, 3, 111-130.

Ahlin, B., Drnovsek, M., \& Hisrich, R. D. (2014). Entrepreneurs' creativity and firm innovation: The moderating role of entrepreneurial self-efficacy. Small Business Economics, 43, 101-117.

Ali, M., Kulik, C. T., \& Metz, I. (2011). The gender diversity-performance in services and manufacturing organizations. The International Journal of Human Resource Management, 22(7), 1464-1485.

Arranz, N., Arrovabe, C. F., \& Fernandez, J. C. (2019). The effect of regional factors in the development of eco-innovations in the firm. Business Strategy and the Environment, 28(7), 1406-1415.

Bauer, M., \& Sinning, M. (2008). An extension of the blinder-oaxaca decomposition to nonlinear models. Advances in Statistical Analysis, 92(2), 197-206.

Becic, M., Vojinic, P. (2018). The Role of Female Top manager in Innovation Activities: Case of CEECs forms. Proceedings of Economics and Finance Conference 6909790, International Institute of Social and Economic Sciences.

Belghiti-Mahut, S., Lafont, A. L., \& Yousfi, O. (2016). Gender gap in innovation: A confused link? Journal of Innovation Economics \& Management, 19(1), 159-177.

Blinder, A. (1973). Wage discrimination: Reduced form and structural estimates. The Journal of Human Resources, 8(4), 436-455.

Boulouta, I. (2013). Hidden connections: The link between board gender diversity and corporate social performance. Journal of Business Ethics, 113(2), 185-197.

Bowonder, B., Anirndha, D., Shambhu, K., \& Abhay, S. (2010). Innovation strategies for creating competitive advantage. Research-Technology Management, 53(3), 19-32.

Brouwer, E., \& Kleinknecht, A. H. (1996). Determinants of innovation: A microeconometric analysis of three alternative innovative output indicators. In A. Kleinkrecht (Ed.), Determinants of innovation: The message from new indicators (pp. 99-124). MacMillan Press.

Carter, D., D’Souza, F., Simkins, B., \& Simpson, W. (2010). The gender and ethnic diversity of US boards and board committees and firm financial performance. Corporate Governance: An International Review, 18(5), 396-414. 
Christiansen, L., Lin, H., Pereira, J., Topalova, P., \& Turk, R. (2017). Unlocking the Potential of greater female employment in Europe. Intereconomics, 52, 5-16.

Dai, Y., Byun, G., \& Ding, F. (2019). The direct and indirect impact of gender diversity in new venture teams on innovation performance. Entrepreneurship Theory and Practice, 43(3), 505-528.

De Mel, S., McKenzie, D. and Woodruff, C. (2009). Innovation Firms or Innovative Owners? Determinants of Innovation in Micro, Small, and Medium Enterprises, IZA Working Paper No. 3962: 1-32

De Saà-Peréz, P., Dìaz-Dìaz, N. L., Aguiar-Dìaz, I., \& Ballesteros-Rodrìguez, J. L. (2015). How diversity contributes to academic research team performance. R\&D Management, 47(2), 165-179.

Dezso, C., \& Ross, D. G. (2012). Does female representation in top management improve firm performance? A Panel data investigation. Strategic Management Journal, 33, 1072-1089.

Diaz-Garcìa, C., Gonzàlez-Moreno, A., \& Sàez-Martinez, F. J. (2013). Gender diversity within R\&D teams: Its impact on radicalness of innovation. Innovation: Organization \& Management, 15(2), $149-160$.

Dohse, D., Goel, R. K., \& Nelson, M. A. (2019). (2019). Female owners versus female managers. Who is better at introducing innovation? The Journal of Technology Transfer, 44, 520-539.

Eriksson-Zetterquist, U. (2007). Gender and new technologies. Gender Work and Organization, 14(4), 305-311.

Even, W. E., \& Macpherson, D. A. (1993). The decline of private-sector unionism and the gender wage gap. The Journal of Human Resources, 28(2), 279-296.

Fagerberg, J., Mowery, D. C., \& Nelson, R. R. (2005). The Oxford Handbook of Innovation. Oxford University Press.

Fairlie, R. (2005a). The absence of the African-American owned business: An analysis of the dynamics of self-employment. Journal of Labor Economics, 17(1), 80-108.

Fairlie, R. (2005b). An extension of the blinder-oaxaca decomposition technique to logit and probit models. Journal of Economic and Social Measurement, 30(4), 305-316.

Fazlıŏlu, B., Dalgıç, B., \& Yereli, A. B. (2019). The effect of innovation on productivity: Evidence from Turkish manufacturing firms. Industry and Innovation, 26(4), 439-460.

Fernandez, J. (2015). The impact of R\&D teams' gender diversity on innovation outputs. International Journal of Entrepreneurship and Small Business, 24(1), 142-162.

Friesenbichler, K., Boheim, M., Laster, D. (2014). Market Competition in Transition Economies: A Literature Review. WIFO Working Paper, no.477/2014.

Gallego, J.M., Gutierrez, L.H. (2018). An Integrated Analysis of the Impact of Gender Diversity on Innovation and Productivity in Manufacturing Firms. IDB Working Paper Series no.865.

Garcia Martinez, M., Zouaghi, F., \& Garcia Marco, T. (2016). Diversity is strategy: The effect of R\&D team diversity on innovative performance. $R \& D$ Management, 47(2), 311-329.

Goedhuys, M., \& Sleuwaegen, L. (2000). Entrepreneurship and growth of entrepreneurial firms in Cote D'Ivoire. Journal of Development Studies, 36(3), 122-145.

Gupta, P. D., Guha, S., \& Krishnaswami, S. S. (2013). Firm growth and its determinants. Journal of Innovation and Entrepreneurship, 2(15), 1-14.

Hillman, A. J., Shropshire, C., \& Cannella, A. A. (2007). Organizational predictors of women of corporate boards. Academy of Management Journal, 50(4), 941-952.

Hodigere, R., \& Bilimoria, D. (2015). Human capital and professional network effects on women's odds of corporate board directorships. Gender in Management, 30(7), 523-550.

Hozer-Kocmiel, M., Misiak-Kwit, S., Lisowska, E., \& Ruminska-Zimny, E. (2017). Gender and innovation in the countries of the Baltic sea region. International Journal of Contemporary Management, 16(1), 109-126.

Jackson, S. E., Joshi, A., \& Erhardt, N. L. (2003). Recent research on team and organizational diversity: SWOT analysis and implications. Journal of Management, 29(6), 801-830.

Latan, H., Chiappetta Jabbour, C.J., Lopes de Sousa Jabbour, A.B., de Camargo Fiorni, P., Foropon, C. (2019). Innovative efforts of ISO9001-certified manufacturing firms: Evidence of links between determinants of innovation, continuous innovation and firm performance. International Journal of Production Economics, in Press.

Levi, M., Li, K., \& Zhang, F. (2015). Director gender and mergers and acquisitions. Journal of Corporate Finance, 28, 185-200.

Nakagawa, Y. (2015). The gender diversity-firm performance relationship by industry type, working hours and inclusiveness: An empirical study of Japanese firms. Journal of Diversity Management, 10(1), 61-78. 
Naudé, W. A., \& Rossouw, S. (2010). Early international entrepreneurship in China: Extent and determinants. Journal of International Entrepreneurship, 8(1), 87-111.

Nielsen, S., \& Huse, M. (2010). Woman directors and board strategic decision making. The moderating role of equality perception. European Management Review, 7(1), 16-29.

Oaxaca, R. (1973). Male-female wage differentials in urban labor markets. International Economic Review, 14(3), 693-709.

Østergaard, C. R., Timmermans, B., \& Kristinsson, K. (2011). Does a different view create something new? The effect of employee diversity on innovation. Research Policy, 40, 500-509.

Popovic Pantic, S. (2014). An analysis of female entrepreneurship and innovation in Serbia in the context of EU competitiveness. Economic Annals, LIX, 200, 61-90.

Quintana-Garca, C., \& Benavides-Velasco, C. (2008). Innovative competence, exploration and exploitation: The influence of technological diversification. Research Policy, 37(3), 492-507.

Ritter-Hayashi, D., Vermeulen, P., \& Knoben, J. (2019). Is this a man's world? The effect of gender diversity and gender equality on firm innovativeness. PLOS ONE, 14(9), e0222443.

Sirec, K., \& Mocnik, D. (2015). Gender based determinants of established entrepreneurs' innovative activity in Southeast Europe. In V. Ramadani, S. Gerguri, \& A. Fayolle (Eds.), Female entrepreneurship in transition economies: trends and challenges. Palgrave Macmillan.

Smith, A., Houghton, S. M., Hood, J. N., \& Ryman, J. A. (2006). Power relationship among top managers: Does top management team power distribution matter for organizational performance? Journal of Business Research, 59(5), 622-629.

Solakoglu, M. N. (2013). The role of gender diversity on firm performance: A regression quantile approach. Applied Economics Letters, 20(17), 1562-1566.

Terjesen, S., Sealy, R., \& Singh, V. (2009). Women directors on corporate boards: A review and research agenda. Corporate Governance: An International Review, 17(3), 320-337.

Teruel, M., Parra, M. D., \& Segarra-Blasco, A. (2015). Gender Diversity and Innovation in manufacturing and service firms. Universitat Rovira I Virgili.

Tomaszewski, M., \& Świadek, A. (2017). The impact of the economic conditions on the innovation activity of the companies from selected Balkan states. Ekonomska Istraživanja / Economic Research, 30(1), 1896-1913.

Triana, M., Richard, O. C., \& Su, W. (2019). Gender diversity in senior management, strategic change, and firm performance: Examining the mediating nature of strategic change in high teach firms. Research Policy, 48, 1681-1693.

Wang, Z., \& Wang, N. (2012). Knowledge sharing, innovation and firm performance. Expert Systems with Applications, 39, 8899-8909.

Wikhamn, W., Wikhamn, B.R. (2019). Gender Diversity and Innovation Performance: Evidence from R\&D Workforce in Sweden. International Journal of Innovation Management.

Xie, L., Zhou, J., Zong, Q., \& Lu, Q. (2020). Gender diversity in R\&D teams and innovation efficiency: Role of innovation context. Research Policy, 49(1), 1-13.

Yun, M. (2000). Decomposition analysis for a binary choice model. IZA.

Yun, M. (2004). Decomposing differences in the first moment. Economics Letters, 82(2), 275-280.

Yun, M. (2005). Hypothesis tests when decomposing differences in the first moment. Journal of Economic and Social Measurement, 30(4), 295-304.

Publisher's Note Springer Nature remains neutral with regard to jurisdictional claims in published maps and institutional affiliations. 